\title{
In vivo Study of Sealing Capability of Raw Propolis Extract and Calcium Hydroxide on Dentin Surface
}

This article was published in the following Dove Press journal:

Clinical, Cosmetic and Investigational Dentistry

Muhamad Roelianto

Dian Agustin Wahjuningrum (1)

Yusuf Bagus Pamungkas

Nanik Zubaidah

Ryza Indah Permatasari

Eska Dianti

Department of Conservative Dentistry, Faculty of Dental Medicine, Universitas Airlangga, Surabaya, Jawa Timur 60132, Indonesia
Correspondence: Dian Agustin

Wahjuningrum

Department of Conservative Dentistry,

Faculty of Dental Medicine, Universitas

Airlangga, Mayjen Prof. Dr. Moestopo 47,

Surabaya, Jawa Timur 60132, Indonesia

Tel +62315030252

Fax +62315022472

Email dian-agustin-w@fkg.unair.ac.id
Aim: This research aimed to investigate the differences in the sealing capability of propolis extracts and $\mathrm{Ca}(\mathrm{OH})_{2}$ on dentin surfaces.

Materials and Methods: Eighteen mandible incisors of Wistar rats were prepared at a depth of $0.5 \mathrm{~mm}$ after which they were randomly divided into 3 groups $(\mathrm{n}=6)$ including control $(\mathrm{C})$, pulp-capped with $\mathrm{Ca}(\mathrm{OH})_{2}$ group (P1), and indirect pulp-capped with propolis extract group (P2). All the cavities were sealed with glass ionomer restorative cement. Moreover, the sections of the teeth were obtained after six Wistar Rats from each group were sacrificed on the second day after treatment. The rats' incisors were cleaved transversally to the area where $\mathrm{Ca}(\mathrm{OH})_{2}$ and propolis extract bonded with dentin for the SEM (scanning electron microscope) analysis and examined using microphotographs test with 5000x magnification. All the samples were measured and examined with spectrophotometry test to determine the bonding distance between $\mathrm{Ca}(\mathrm{OH})_{2}$ and dentin, as well as propolis extract and dentin. The result from the two tests was analyzed with SPSS using an independent $t$-test at $\mathrm{p}<0.05$.

Results: There were significant differences between the calcium hydroxide and propolis extract groups $(p<0.05)$ based on the results obtained in the form of spectrums chemical functional groups of spectrophotometry examination. No new chemical bonding or compound was also observed to have been formed between propolis extract with dentin as well as calcium hydroxide with dentin.

Conclusion: The adaptation or sealing capability of propolis extract was found to be better than calcium hydroxide to the dentin surface.

Keywords: pulp capping, sealing ability, calcium hydroxide, propolis, scanning electron microscope, spectrophotometry

\section{Introduction}

Dental caries is an infectious disease affecting dental hard tissues and the process usually starts with the release of chemical product produced by bacteria to damage the inorganic and organic components. This chemical product is organic acids produced as a by-product of carbohydrate metabolism ${ }^{1}$ and also has the ability to pass through dentinal tubules thereby affecting the pulp vitality which functions to initiate several defense mechanisms to protect the body from bacterial invasion. The infected dentin in contact with pulp tissue is likely to encourage inflammation and discourage reparative dentin formation. Pulp capping is one of the treatments aimed to sustain pulp tissue vitality and avoid more extensive approaches dictated by extraction or endodontic treatment. ${ }^{2,3}$ The process can be applied as a direct pulp cap with the medicament placed directly over the exposed pulp, or as an indirect 
pulp cap, in which a cavity liner or sealer is placed over the affected dentin. This treatment is applied to maintain pulp vitality ${ }^{4}$ and the possibility of failure in the process is mainly caused by bacterial contamination due to the microleakage under the capping materials.

Microleakage is a phenomenon where there is no bond formation or release of adhesions between the restorative material and the tooth structure, enamel, and dentin. It is, however, possible to have good adaptations or sealing capability with dentin surface and prevent the micro-leakage through the use of a material with power of attachment or adhesion to create an optimal adaptation between the two substances due to the inherent tension force existing between them. ${ }^{5}$ This is achievable either mechanically or chemically, with the chemical aspect observed to be attached to the diffusion and absorption or ion exchange mechanism initiated by the material's contact with the dental tissues. Meanwhile, the mechanical attachment mechanism involves the material being mechanically interlocked into the micro undercut on the tooth surface. ${ }^{6}$ This, therefore, means the sealing capability of pulp capping material on the dentin surface plays an important role in preventing bacterial contamination by forming a bridge.

Calcium hydroxide $\left(\mathrm{Ca}(\mathrm{OH})_{2}\right)$ is widely used as a pulpcap material but it has been discovered not to have a good adaptation to the dentin surface nor does it consistently stimulate the differentiation of odontoblasts and has also proven to be cytotoxic to cell cultures. ${ }^{7}$ Moreover, it is not stable under restorations after long-term usage, thereby, leaving the cavity unprotected and the restoration unsupported. This happens when $\mathrm{Ca}(\mathrm{OH})_{2}$ has a contact with dentinal fluid which dissolves the material and affect its effectiveness. ${ }^{8}$ The solubility of calcium hydroxide is very low which is 0.16 grams in $100 \mathrm{~mL}$ of water at $30^{\circ} \mathrm{C}$ and this decomposes to produce insoluble particles including hydroxyl ions $\left(\mathrm{OH}^{-}\right)$ and calcium ions $\left(\mathrm{Ca}^{2+}\right){ }^{9}$ The hydroxyl ions make the environment alkaline with the $\mathrm{pH}$ increased to 12.5 at $37^{\circ} \mathrm{C}$ and are antimicrobial. ${ }^{10,11}$ This further affects the adaptation of the compound in the dentin.

Propolis is a resinous yellow-brown to dark brown compound collected by bees (Apis mellifera) from tree buds, sap flows, shrubs, or other vegetable sources. It is a potent antimicrobial, antioxidant, and anti-inflammatory agent, ${ }^{12}$ and being a natural substance it is believed to have fairly good adaptability to the dentin surface. Propolis also contains flavonoids which allegedly has the ability to produce crystals required to seal the dentinal tubules and reduce fluid movement in the dentin and, consequently, its sensibility. ${ }^{13}$
Propolis extract has been reported to have low cytotoxicity in gingival fibroblasts and this was considered toxic at $92.70 \mu \mathrm{g} / \mathrm{mL}$ concentration. ${ }^{14}$

There are limited studies on propolis as an indirect pulp capping material; therefore, this study was conducted to determine the material with better sealing capability between propolis and calcium hydroxide. An in vivo approach was used with the results obtained through the simulation of the biological conditions found in a live subject because an in vitro study has been previously conducted on the antibacterial attributes of propolis and the finding produced a successful indirect pulp capping. ${ }^{15}$

\section{Materials and Methods Preparation of Propolis Extract}

Propolis extract was obtained by maceration from raw Propolis collected from Apis Melivera sp bee farms in Malang-Indonesia. This involved the maceration of 500 grams of raw propolis with $500 \mathrm{~mL} 96 \%$ ethanol in a closed container and the mixture shaken using a shaker at a speed of $80 \mathrm{rpm}$. The process was stopped after 7 days and the content was filtered and this was followed by 24hour treatment repeated for another 7 days with the ethanol color observed not to have changed. This, therefore, makes the total maceration time to be 14 days. Moreover, the ethanol solution was evaporated using a vacuum evaporator at $50-60^{\circ} \mathrm{C}$ to produce a thick brownish liquid from the propolis extract. This was further diluted with distilled water to have $1 \mathrm{mg} / \mathrm{mL}$ concentration for the indirect pulp capping material which was later placed as a thin layer on the dentin surface.

\section{Preparation of the Samples}

The procedures used in this study were in accordance with the ethical standards instituted by the Responsible Committee on animal care and use experimentation in the Faculty of Dental Medicine No: 141/KKEPK.FKG/ IX/2014. The research involved the use of 18 male Wistar rats weighing 200-230 g and aged 10-12 weeks as samples and they were further divided into 3 groups $(\mathrm{n}=6)$ including Control $(\mathrm{P} 0)$ which was without any treatment, cavity pulp-capped with $\mathrm{Ca}(\mathrm{OH})_{2}$ (Pulpdent, Watertown, USA) known as (P1), and cavity pulp-capped with propolis extract known as (P2). The anesthetic injections used were ketamine $\mathrm{HCl} 50 \mathrm{mg} / \mathrm{kg} \mathrm{BB}$ and xylazine $\mathrm{HCl} 10 \mathrm{mg} / \mathrm{kg}$ which were injected intramuscularly in the femoral caudal extremity. Furthermore, the cavity class V 
was drilled up to $0.5 \mathrm{~mm}$ in depth without exposing the pulp in the mandible incisor using a slow-speed handpiece with fissure diamond bur (Coltene, Altstätten, Switzerland) at $1500 \mathrm{rpm}$ speed before it was irrigated with sterile saline and dried with a cotton pellet. The pulp cap material was applied in a thin layer on the surface of the dentin incisor mandible after which the cavity was sealed using a Dental GC Fuji II Glass Ionomer Restorative Cement. Each group consisted of six samples and observed 2 days after treatment and the mandible teeth were decapitated. All the groups of the experimental animals were provided uniform standard feed during adaptation up to the end of the treatment. On the second day after the treatment, they were sacrificed to retrieve the mandible with the control and treated group of rats anesthetized using ketamine $\mathrm{HCl}$ at a dose of $50 \mathrm{mg} / \mathrm{kg} \mathrm{BB}$ and xylazine $\mathrm{HCl} 10 \mathrm{mg} / \mathrm{kg}$ injected intramuscularly in the femoral caudal extremity. They were laid on the dissecting tray after they showed no painful response to the anesthetization with each leg fixed using a needle. The incisor teeth including the mandible were cut using a blade and fixed in a pot filled with formalin.

\section{SEM Examination}

The samples were prepared for SEM examination by cutting the mandible incisor teeth transversally with the area limited to the places covered with the pulp capping materials and dentin. They were fixed and coated before being inserted into the SEM machine. Three points of each sample and the distance between the pulp capping material with dentin were measured and calculated based on the P1 image taken at 5000x magnification. The adhesion of the $\mathrm{Ca}(\mathrm{OH})_{2}$ and Propolis extract materials to the dentin surface was determined using the Scanning Electron Microscope (Hitachi, Krefeld, Germany) while spectrophotometry (Hitachi, Tokyo, Japan) test was applied to evaluate the chemical bonding.

\section{Spectrophotometry Test}

The Wistar rat incisor tooth samples prepared and grounded to a powder were placed into a test machine for examination while $\mathrm{KBr}$ powder (potassium bromine) was applied as a conductor.

\section{Statistical Analysis}

The SEM and spectrophotometry results were analyzed with SPSS version 21 (IBM, New York, USA) using an independent $t$-test at $\mathrm{p}<0.05$.

\section{Results}

The interpretation of Propolis and $\mathrm{Ca}(\mathrm{OH})_{2}$ pulp capping material SEM image. The microleakage of the group treated with propolis was found to be significantly smaller with $0.64 \mu \mathrm{m}$ mean value than those treated with $\mathrm{Ca}$ $(\mathrm{OH})_{2}(\mathrm{P}=0.002)$ with $1.71 \mu \mathrm{m}$ mean value.

\section{Discussion}

The SEM analysis showed there is a significant difference in the distance between the propolis extract and calcium hydroxide on the surface of the Wistar rats tooth dentin at $p=0.02$ and mean value of $p<0.05$. This means there are meaningful differences in the kinds of materials to be used for pulp capping.

The 5000x magnification field of view used in the SEM to obtain a clearer picture for the group treated with Calcium Hydroxide did not affect the results due to the use of a scale to measure the visible distance. The group had a greater distance with $1.71462 \mu \mathrm{m}$ compared to the group treated with propolis extract which was 0.64581 $\mu \mathrm{m}$. Moreover, the interpretation of SEM image of calcium hydroxide-treated group shown in Figure 1 describes did not provide a good adaptation to the dentin and was also unstable under restoration leaving unprotected cavity and unsupported restoration.

The solubility of calcium hydroxide in water was also found to be low with 0.16 grams in $100 \mathrm{~mL}$ of water at $30^{\circ}$ $\mathrm{C}$ and this produced a lot of insoluble particles including calcium ions and hydroxyl ions. Its application makes the dentin surface to be wet thereby reducing its sealing ability. ${ }^{8,9}$ Meanwhile, the interpretation of SEM image of propolis extracts treated group shown in Figure 2 showed

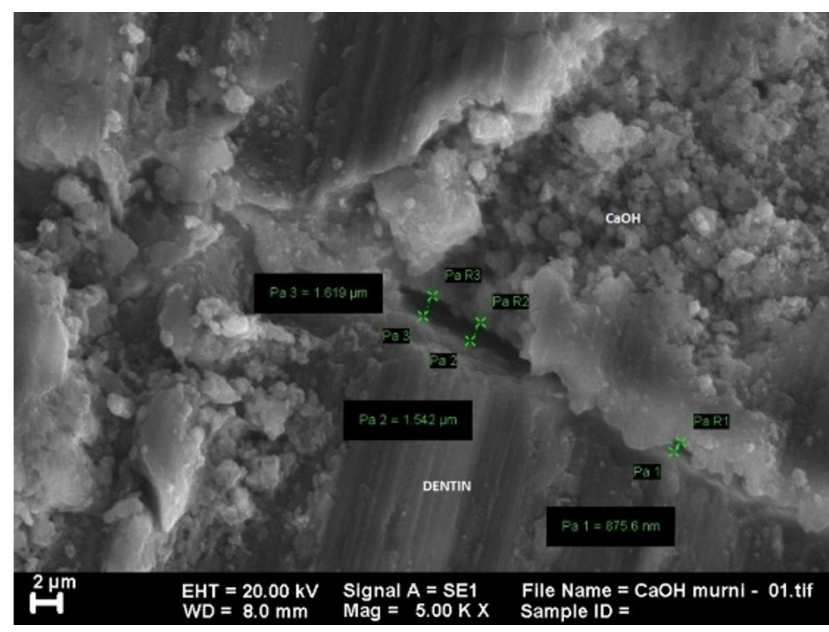

Figure I SEM image of group treated with $\mathrm{CaOH}_{2}$ at 5000 x magnification. 


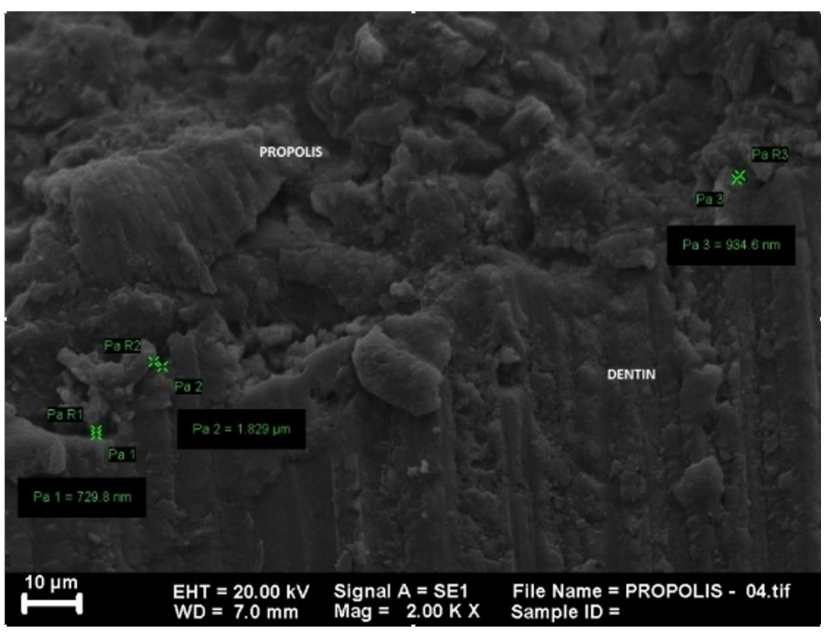

Figure 2 SEM image of group treated with propolis extract at 2000x magnification.

better adaptation to the dentin. Propolis has hydrophilic properties and this makes them have better sealing ability. This observation in line with Sforcin and Bankova's ${ }^{6}$ findings that the compound has good solubility in water.

The quite good adaptability of the propolis extract with the dentine surface was associated with the bee wax and flavonoids contained in it which was allegedly reported to have the ability to produce crystals after reacting with dentin which later binds and close the open tubules. ${ }^{16}$

The spectrophotometry analysis shown in Figures 3-7 describes the spectrum of functional groups contained in each sample. The treatment group with the propolis extract was observed to have produced a new compound with a mixture of weak chemical bonds including Van Der Waal and hydrogen bonds which are noncovalent and differ in geometry, strength, and specificity. ${ }^{17}$ The treatment group with calcium hydroxide did not produce any new compound but also had the same weak chemical bonds ${ }^{18}$ with the Van Der Waals obtained from the $\mathrm{Ca}^{2+}$ ionic charge ions on calcium hydroxide and the $\mathrm{O}^{-}$ions on dentin while the hydrogen bond was based on calcium ions from calcium hydroxide and $\mathrm{OH}^{-}$from dentin. ${ }^{18,19}$ Moreover, the weak chemical and alleged presence of ionic bond between the propolis extract and dentin were associated with the bees' wax with the formula $\mathrm{C}_{13} \mathrm{H}_{27} \mathrm{CO}_{2} \mathrm{C}_{26} \mathrm{H}_{53}$ and 12 types of flavonoids with different chemical formula but generally having $\mathrm{C}, \mathrm{H}$, and $\mathrm{O}$ elements found in the propolis extract which reacted with the hydroxyapatite $\left(\mathrm{Ca}_{10}\left(\mathrm{PO}_{4}\right)_{6} \mathrm{OH}_{2}\right)$ contained in the dentine. ${ }^{20}$

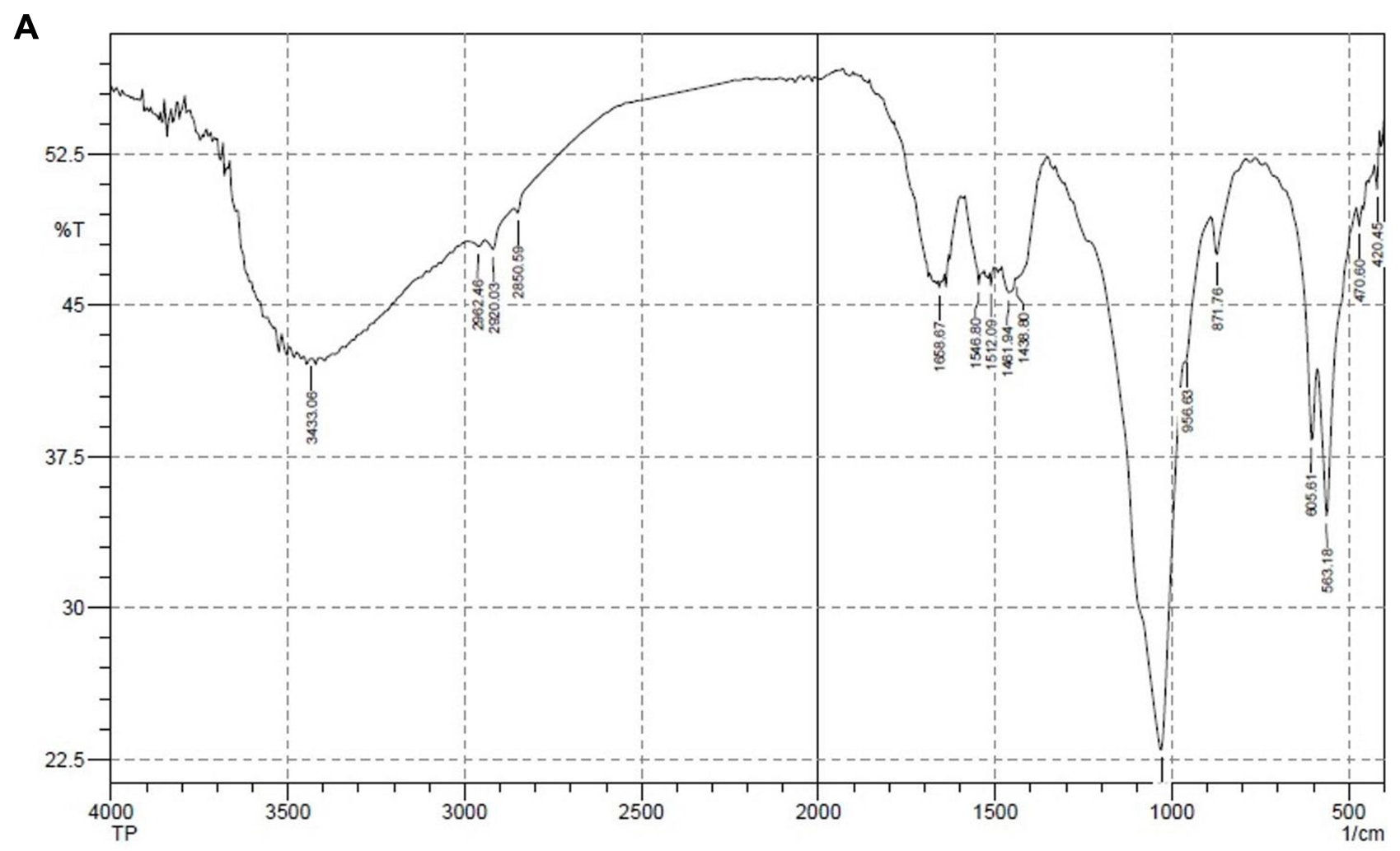

Figure 3 Spectrum image of dentin. 


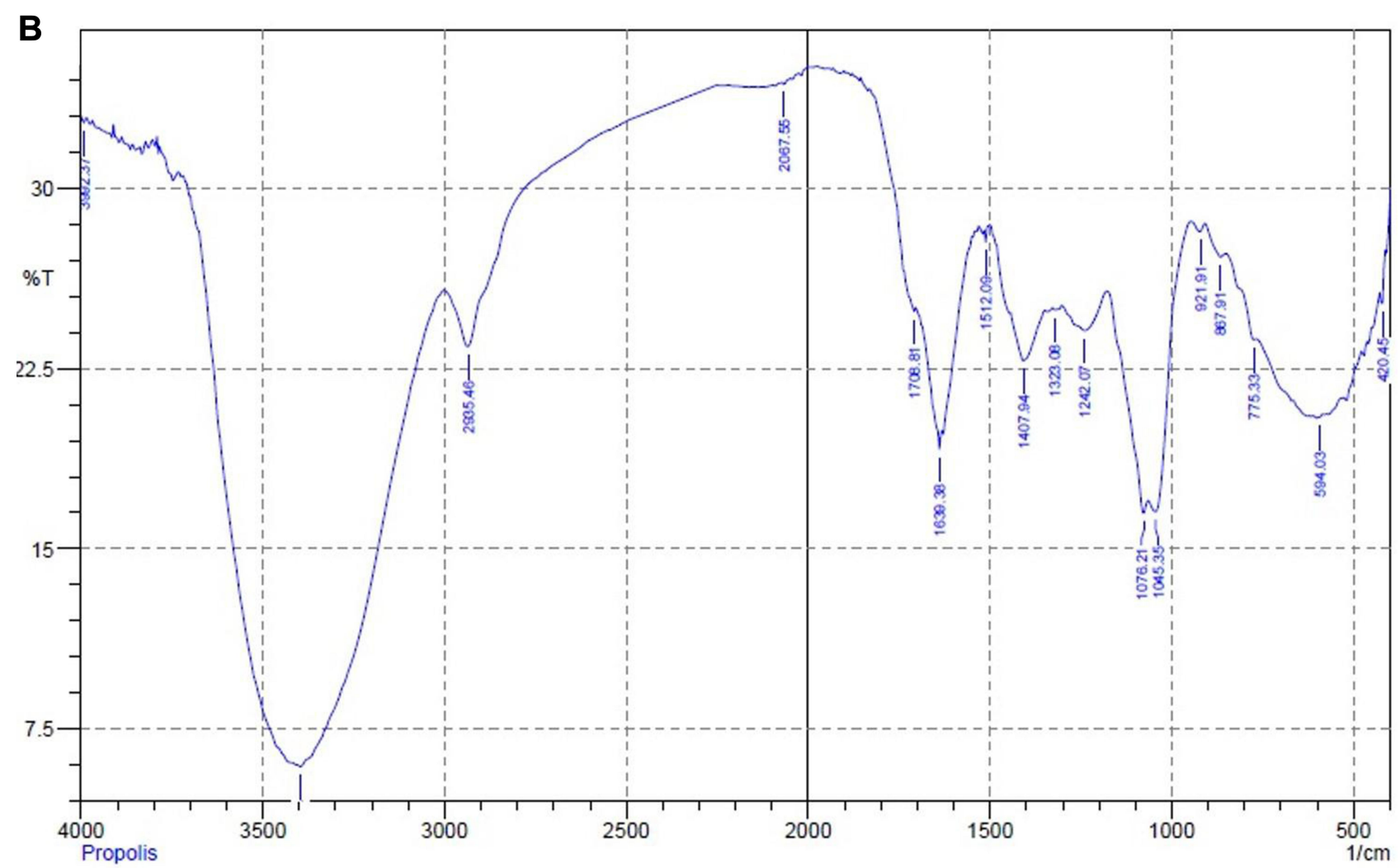

Figure 4 Spectrum image of propolis extract.

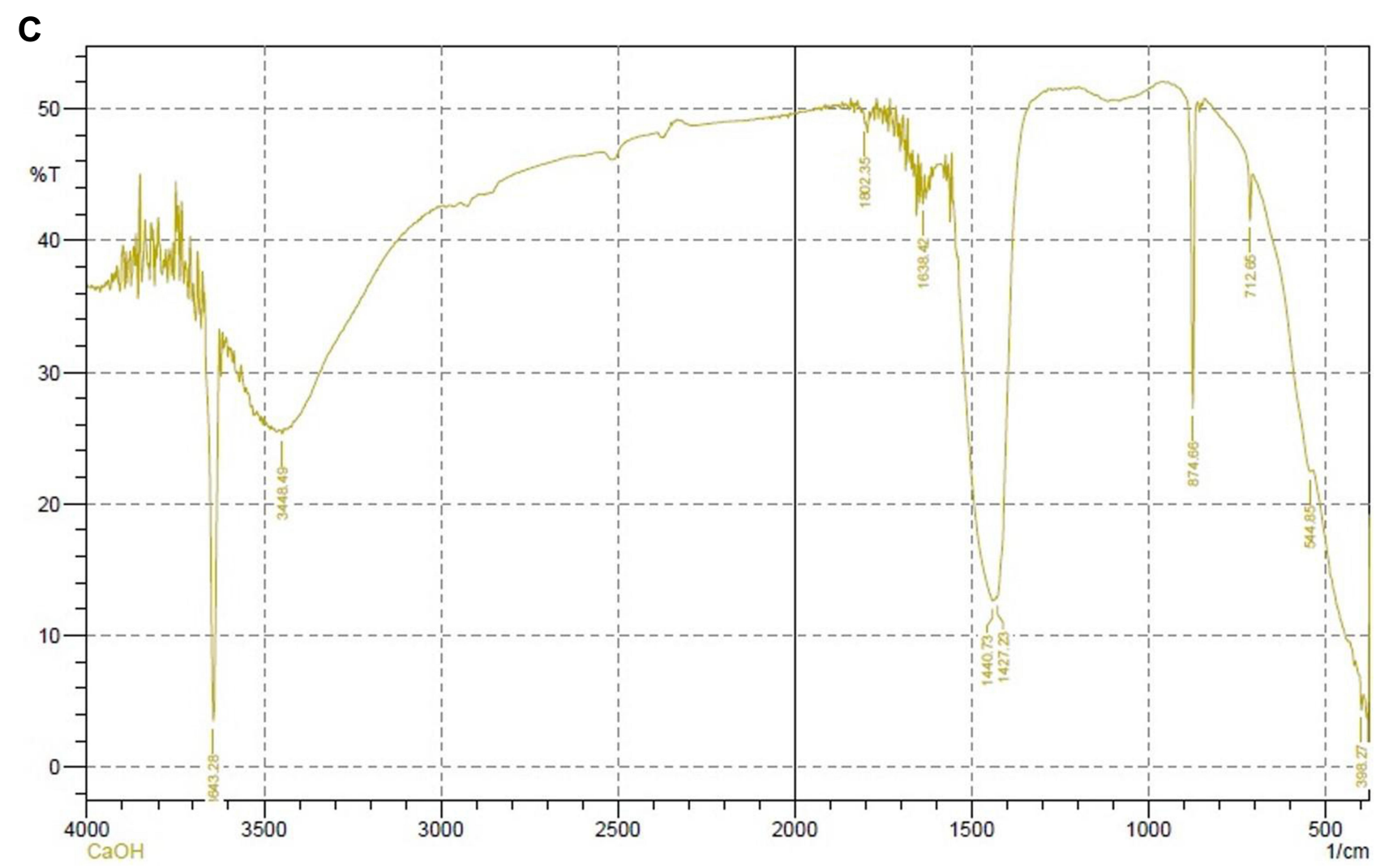

Figure 5 Spectrum image of dentin treated with propolis extract. 


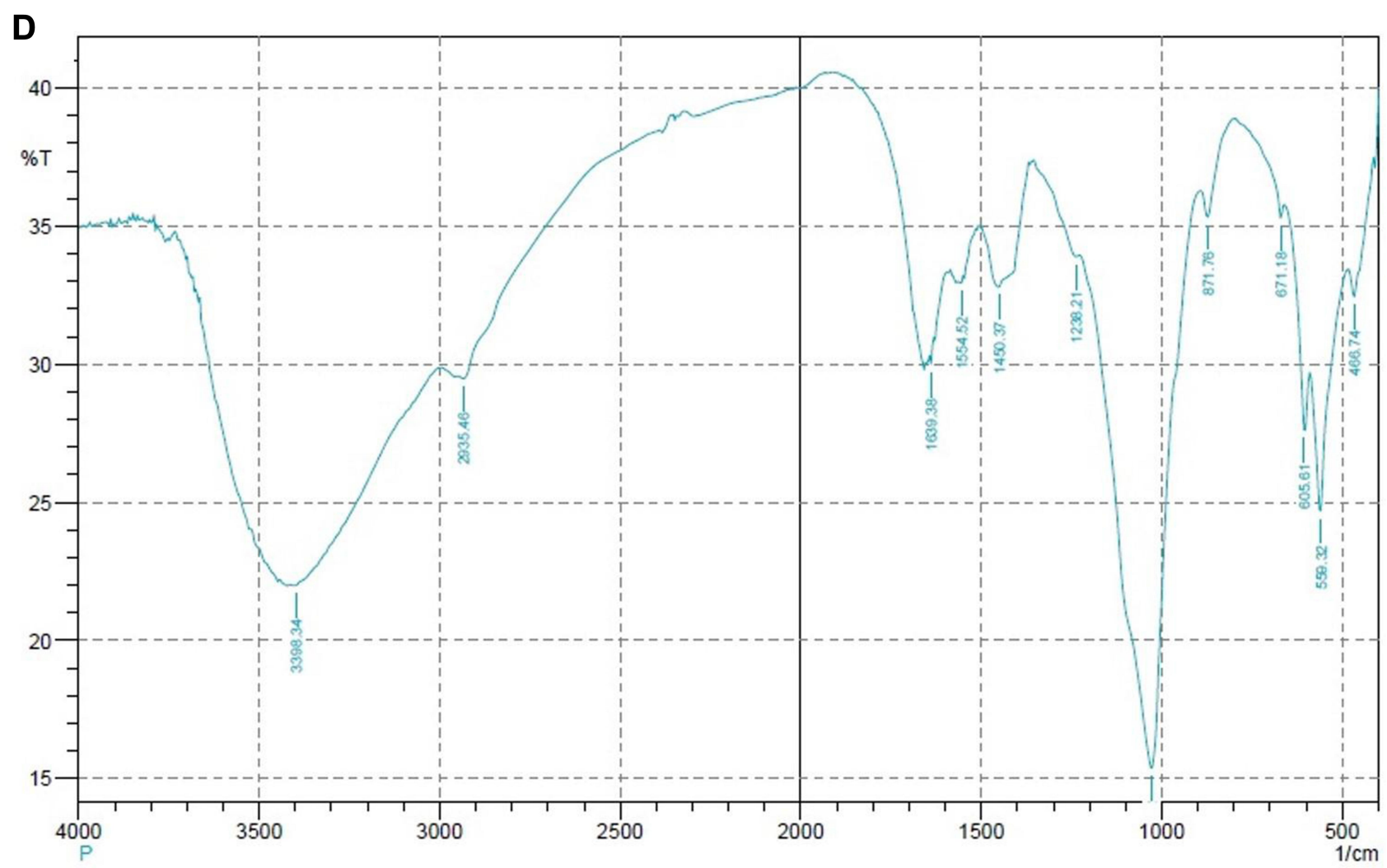

Figure 6 Spectrum image of calcium hydroxide.

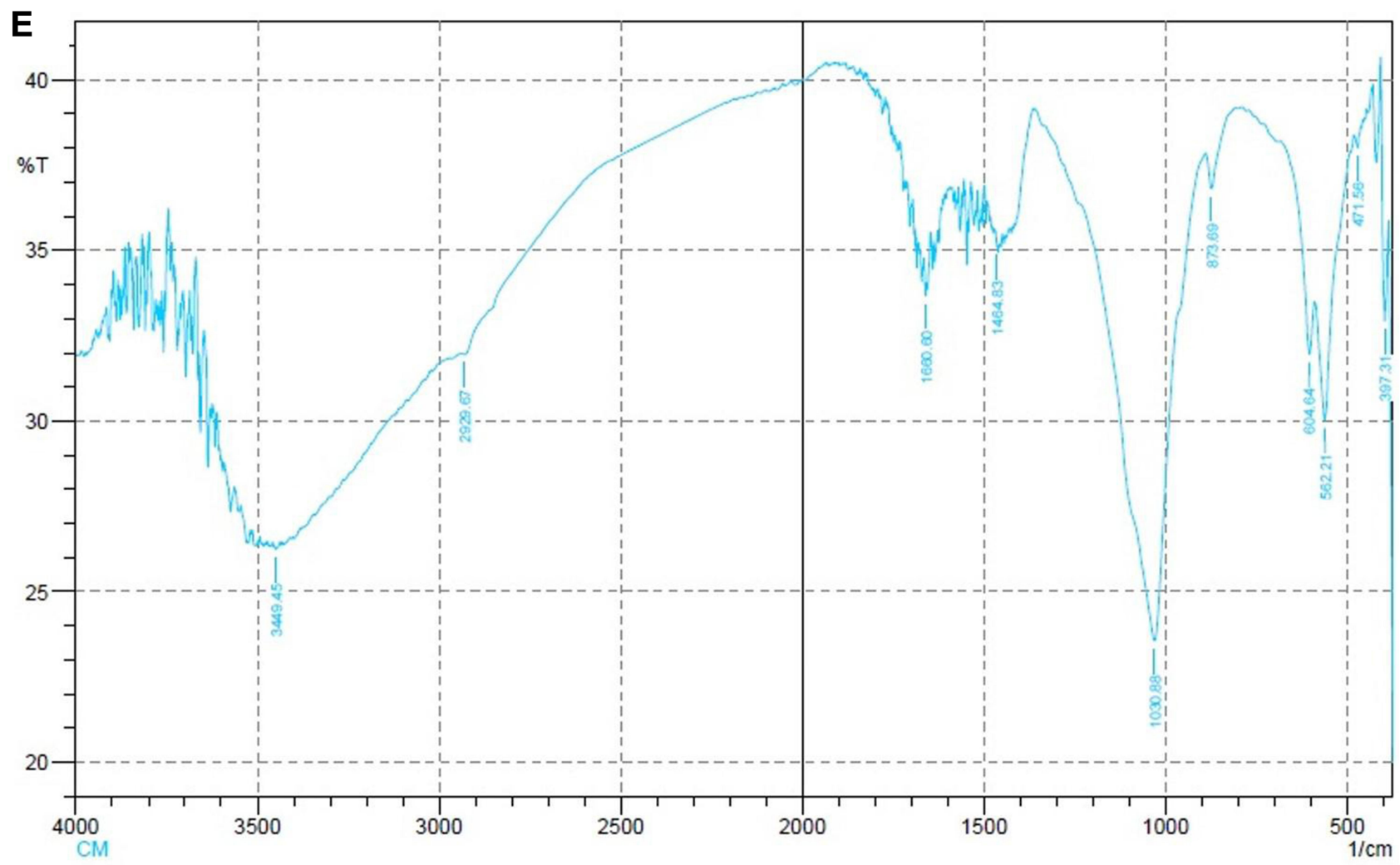

Figure 7 Spectrum image of dentin treated with calcium hydroxide. 


\section{Conclusion}

The sealing capability of propolis as an indirect pulp capping material is better than calcium hydroxide.

\section{Disclosure}

The authors report no conflicts of interest for this work.

\section{References}

1. Featherstone J. Dental caries: a dynamic disease process. Aust Dent J. 2008;53:286-291. doi:10.1111/j.1834-7819.2008.00064.x

2. Bansal P, Kapur S, Ajwani P. Effect of mineral trioxide aggregate as a direct pulp capping agent in cariously exposed permanent teeth. Saudi Endod J. 2014;4:135-40. doi:10.4103/1658-5984.138146

3. Ho C, Argáez C. Endodontic therapy interventions for root canal failure in permanent dentition: a review of clinical effectiveness, cost-effectiveness, and guidelines; 2017.

4. Hilton TJ. Keys to clinical success with pulp capping: a review of the literature. Oper Dent. 2009;34:615-625. doi:10.2341/09-132-0

5. Von Fraunhofer JA. Adhesion and cohesion. Int J Dent. 2012;8.

6. Sforcin JM, Bankova V. Propolis: is there a potential for the development of new drugs? J Ethnopharmacol. 2011;133:253-260. doi:10.1016/j.jep.2010.10.032

7. Bogen G, Kim JS, Bakland LK. Direct pulp capping with mineral trioxide aggregate. $J$ Am Dent Assoc. 2008;139:305-315. doi:10.14219/jada.archive.2008.0160

8. Francisconi LF, Freitas APD, Scaffa PMC, Mondelli RFL, Francisconi PAS. Water sorption and solubility of different selfadhesive cements. J Appl Oral Sci. 2009;17:472. doi:10.1590/ S1678-77572009000500014

9. Safavi K, Nakayama TA. Influence of mixing vehicle on dissociation of calcium hydroxide in solution. J Endod. 2000;26:649-651. doi:10.1097/00004770-200011000-00004

10. Solak H, Öztan MD. The $\mathrm{pH}$ changes of four different calcium hydroxide mixtures used for intracanal medication. J Oral Rehabil. 2003;30:436-439. doi:10.1046/j.1365-2842.2003.01062.x
11. Komabayashi T, D’souza RN, Dechow PC, Safavi KE, Spångberg LSW. Particle size and shape of calcium hydroxide. NIH Public Access. 2009;35:284-287.

12. Garg P, Tyagi SP, Sinha DJ, Singh UP, Malik V, Maccune ER. Comparison of antimicrobial efficacy of propolis, Morinda citrifolia, Azadirachta indica, triphala, green tea polyphenols and 5.25\% sodium hypochlorite against Enterococcus fecalis biofilm. Saudi Endod J. 2014;4:122-7. doi:10.4103/1658-5984.138141

13. Hongal S, Torwane NA, Goel P, Chandrashekar B. The effect of $30 \%$ ethanolic extract of Indian propolis on replica of human dentin compared against commercially available desensitizing agent: a methodological SEM study in vitro. Pharmacognosy Res. 2014;6:113. doi:10.4103/0974-8490.129026

14. Mooduto L, Fredline C, Sampoerno G, Goenharto S, Puteri FH, Wahjuningrum DA. Cytotoxicity of sodium hypochlorite, chlorhexidine and propolis on human periodontal ligament fibroblast cell. $J$ Int Dent Med Res. 2019;12:476-480.

15. Wahjuningrum DA, Subijanto A. Influence of extract propolis on the adherence of enterococcus faecalis as a candidate root canal irrigation solution. Int J Sci Clin Lab. 2015;8:1-11.

16. Sales-peres SHDC, Carvalho FND, Marsicano JA, et al. Effect of propolis gel on the in vitro reduction of dentin permeability. $J \mathrm{Appl}$ Oral Sci. 2010;318-323.

17. Hubbard RE. Hydrogen bonds in proteins: role and strength. eLS. 2001;1-7.

18. Gribova V, Crouzier T, Picart C. A material's point of view on recent developments of polymeric biomaterials: control of mechanical and biochemical properties. J Mater Chem. 2011;21:14354-14366. doi:10.1039/c1jm11372k

19. Estrela C, Holland R. Calcium hydroxide: study based on scientific evidences. J Appl Oral Sci. 2003;11:269-282. doi:10.1590/S167877572003000400002

20. Zheng Y-Z, Zhou Y, Liang Q, Chen D-F, Guo R, Lai R-C. Hydrogenbonding interactions between apigenin and ethanol/water: a theoretical study. Sci Rep. 2016;6:34647. doi:10.1038/srep34647
Clinical, Cosmetic and Investigational Dentistry

\section{Publish your work in this journal}

Clinical, Cosmetic and Investigational Dentistry is an international, peer-reviewed, open access, online journal focusing on the latest clinical and experimental research in dentistry with specific emphasis on cosmetic interventions. Innovative developments in dental materials, techniques and devices that improve outcomes and patient satisfaction and preference will be highlighted. The manuscript management system is completely online and includes a very quick and fair peer-review system, which is all easy to use. Visit http://www.dovepress.com/testimonials.php to read real quotes from published authors. 